\title{
Strategi Perbankan Syariah Dalam MenghadapiPembiayaan Dengan Akad Mudharabah Yang Bermasalah (Studi Di Bri Syariah Pamekasan)
}

\author{
Syamsul Arifin \\ Djoko Subagyo \\ e-mail:syamsularifin181@gmail.com
}

\begin{abstract}
Islamic banking has a main function to distribute funds to the community in need in the form of financing. Financing is a large part of the assets of sharia banks that must be maintained in term of quality. Financing is one of the functions of sharia banks by distributing funds to the community in need (user of funds). One of the contracts used by sharia banks in distributing funds in the form of financing is mudharabah contract. The mudharabah contract is a profit-sharing agreement when the shohibul mall /rabbul mall provides capital (100 percent) to mudharib, to engage in productive activities in which the profit generated will be divided among them according to the agreement specified in the contract.

This study is aimed to know and understand how the application of mudaraba contracts and banking strategies in overcoming a financing with mudaraba contracts that are problematic, and to know and understand whether the applied strategy is in accordance with the Fatwa (policies) of DSN MUI.

The method used in this research is descriptive qualitative research method or naturalistic research because the research is done on natural condition (natural setting). This descriptive qualitative research method is used to get in-depth data, a data that contains meaning.

The findings of the research done in BRI Syariah Pamekasan in facing the financing problems with the mudharabah contract, found two problems. First, the problem arising from the internal banking itself, this problem occurs when BRI Syraiah employees do not run the SOP (procedures) that has been set. Second problem is the external factor of banking. This problem occurs because mudharib/ fund manager has moral hazard. For example, by not using the funds for productive business but used for consumptive costs.

Efforts done by BRI Syariah Pamekasan dealing with mudharabah financing problem is by using two approaches. First, the pre-customer approach. This approach focuses on selecting prospective customers both in terms of behavior/ character and business run. Second, the postcustomer approach. This approach is carried out when the financing has been distributed to customers and experiencing non-performing financing. This is done by monitoring and restructuring
\end{abstract}

Keywords: Financing, mudharabah contract, banking strategy. 


\section{PENDAHULUAN}

Pasca krisis moneter (1997/1998), bank syariah mulai dikenal orang bahkan dikalangan bank konvensional, kendali bank syariah di Indonesia telah berdiri sejak 1992. Krisis moneter yang menghancurkan beberapa bank konvensional membuat para pakar bankir mulai berfikir dan mencarai alternatif perbankan dengan sistem syariah.

Pendirian Bank Syariah medahului penetapan peraturannya adalah sesuatu yang unik, karena tidak didukung oleh aturan khusus mengenai perbankan syariah sebagai payung hukum. Pendirian Bank Syariah didirikan tahun 1991 sedangkan aturan tentang bagi hasil ditetapkan tahun 1992. Keunikan bank ini terdapat pada sistem yang menjadi landasa operasional bank, yaitu sistem bagi bagi hasil keuntungan dan kerugian (loss and profit sharing), mengeyampingkan sistem bunga (interest). Bank-bank yang ada pada saat itu mengacu kepada Undang-undang Nomor 14 Tahun 1967 tentang Pokok-Pokok Perbankan, yang menyatakan semuan bank dalam menjalankan kegiatan usahanya menganut sistem bunga. ${ }^{1}$

Prinsip perbankan syariah merupakan bagian dari ajaran Islam yang berkaitan dengan ekonomi. Salah satu prinsip dalam ekonomi Islam adalah larangan riba dalam berbagai bentuknya, dan menggunakan sistem antara lain prinsip bagi hasil. Dengan prinsip bagi hasil, Bank Syariah dapat menciptakan iklim investasi yang sehat dan adil karena semua pihak dapat saling berbagi baik keuntungan maupun potensi risiko yang timbul sehingga akan menciptakan posisi yang berimbang antara bank dan nasabahnya. Dalam jangka panjang, hal ini akan mendorong pemerataan ekonomi

${ }^{1}$ Atang Abd. Hakim, Fiqih Perbankan Syariah Transformasi Fiqih Muamalah ke dalam Peraturan Perundang-undangan, (Bandung: Refika Aditama, 2011), 9 nasional karena hasil keuntungan tidak hanya dinikmati oleh pemilik modal saja, tetapi juga oleh pengelola modal. ${ }^{2}$

Fungsi utama bank syariah adalah menghimpun dana dari masyarakat dalam bentuk titipan dan investasi, memyalurkannya dana kepada masyarakat yang membutuhkan, dan juga memberikan pelayanan dalam bentuk jasa perbankan syariah. ${ }^{3}$ Penyaluran pembiayaan pada kuartal I tahun 2017, PT BRI Syariah mencatat penyaluran pembiayaan mencapai $\mathrm{Rp} 17,98$ triliun, naik 6,45 persen dibanding kuartal I 2016 sebesar Rp. 16,89 triliun. ${ }^{4}$ Bahkan pada tahun 2017 bulan Agustus jumlah pembiayaan yang tersalurkan oleh Bank BRI Syariah mencapai Rp. 18,71 triliun, jumlah tersebut tercatat sudah menembus 92,25 persen dari total target outstanding pembiayaan akhir tahun sebesar Rp. 19,65 triliun. ${ }^{5}$

Dengan jumlah penyaluran pembiayaan yang begitu besar, tentunya BRI Syariah dalam menjalankan usahanya tidak semudah dengan apa yang dicita-citakan dan yang diamanatkan oleh peraturan perundang-undangan yang berlaku. Bank syariah dalam menjalankan fungsinya masih banyak menghadapi tantangan yang membuat penetrasi dan perkembangannya menjadi tertahan, salah satu bentuk permasalahan tersebut adalah terletak pada pembiayaan yang bermasalah atau non performing financing (NPF).

Pembiayaan merupakan sebagian besar dari aset bank syariah yang harus dijaga kualitasnya. Pembiayaan merupakan salah satu fungsi dari bank syariah yaitu menyalurkan dana kepada masyarakat yang membutuhkan (user of fund). Masyarakat dapat memperoleh pembiayaan dari bank asalkan dapat memenuhi

\footnotetext{
${ }^{2}$ Penjelasan Undang-udang Nomor 21 Tahun 2008 tentang Perbankan Syariah.

${ }^{3}$ Ismail, Perbankan Syariah, (Jakarta: Kencana Prenada Media Group, 2014), 39

${ }^{4} \mathrm{http}: / /$ www.dream.co.id di akses tanggal 12 Januari 2018

${ }^{5}$ http://www.kontan.co.id diakses tanggal 12 Januari 2018
} 
ketentuan dan persyaratan yang berlaku. Dari kegiatan tersebut bank akan memperoleh return atau pendapatan. ${ }^{6}$

Pembiayaan atau financingmerupakan pendanaan yang disediakan oleh satu pihak untuk pihak lain guna mendukung investasi, baik yang dilakukan sendiri maupun lembaga. Dengan demikian ia senantiasa berkaitan dengan aktivitas bisnis. ${ }^{7}$ Penyaluran dalam bentuk pembiayaan didasarkan pada kepercayaan oleh pemilik dana kepada pengguna dana. Sehingga penerima dana berkewajiban mengembalikan pembiayaan yang telah diterimanya sesuai dengan jangka waktu yang telah diperjanjikan dalam akad.

Akad mudharabahmerupakan akad kerjasama usaha antara dua pihak di mana pihak pertama (shahibul maal) menyediakan seluruh modal (100\%) modal, sedangkan pihak kedua menjadi pengelola. Keuntungan usaha secara secara mudharabah dibagi menurut kesepakatan yang dituangkan dalam kontrak, sedangkan apabila rugi ditanggung oleh pemilik modal selama kerugian itu diakibatkan karena kecurangan atau kelalaian pengelola, si pengelola harus bertanggung jawab atas kerugian tersebut. ${ }^{8}$

Berdasarkan problematika tersebut di atas, penulis sangat tertarik untuk melakukan penelitian yang lebih mendalam terhadap "Strategi Perbankan Syariah dalam Menghadapi Pembiayaan dengan Akad Mudharabah Yang Bermasalah (Studi di BRI Syariah Pamekasan."

Metode penelitian adalah metode yang digunakan dalam aktivitas penelitian. dan metodologi adalah ilmu tentang berbagai

\footnotetext{
${ }^{6}$ Ismail, Perbankan Syariah, (Jakarta: Kencana Prenada Media Group, 2014), 41 ${ }^{7}$ Atang Abd. Hakim, Fiqih Perbankan Syariah Transformasi fiqih Muamalah ke dalm Peraturan Perundang-undangan (Bandung: PT. Refika Aditama, 2011), 219

${ }^{8}$ Muhammad Syafii Antonio, Bank Syariah Dari Teori Ke Praktik, (Depok, Gema Insani, 2017), 95
}

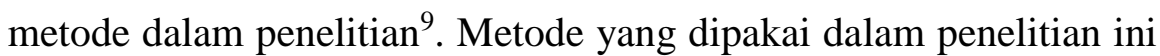
adalah metode penelitian deskriptif kualitatif atau penelitian naturalistik karena penelitiannya dilakukan pada kondisi yang alamiah (natural setting). Deskriptif dalam pengertiannya adalah pencarian fakta dengan interpretasi yang tepat. ${ }^{10}$ Kualitatif adalah penelitian yang menggunakan kata-kata atau gambar dan bukan angka-angka, seandainya dalam penelitian tersebut terdapat angkaangka, maka sifatnya hanya sebagai penunjang saja. ${ }^{11}$

Jenis penelitian ini termasuk studi kasus atau penelitian lapangan (field research) adalah karena informasi dan data yang diperlukan didapat dari BRI Syariah Cabang Pamekekasan yang bersifat deskriptif. Metode pendekatan menggunakan dua cara pendekatan yakni, Yuridis Normatif, yaitu cara pandang dengan melihat ketentuan atau aturan hukum dalam perumusan aturan perundang-undangan yang berkaitan dengan permasalahan yang ada, atau menelaah semua undang-undang dan regulasi yang bersangkut paut dengan permasalahan yang ada. ${ }^{12}$ Serta pendekatan Yuridis Sosiologis, yaitu pendekatan tidak hanya melihat permasalahan hukum dalam perumusan atau perundang-undangan yang ada tetapi melihat permasalahan hukum itu dalam pelaksanaannya atau melihat bagaimana dilaksanakannya suatu aturan hukum kedalam realitanya. Adapun tehnik pengumpulan data yang gunakan adalah interview/wawancara, studi kepustakaan (library risearch), dan dokumentasi. Sedangkan analis data yang digunakan adalan editing dan analizing.

\footnotetext{
${ }^{9}$ Boedi Abdullah, Beni Ahmad Saebani, Metode Penelitian Ekonomi Islam Muamalah, (Bandung: CV. Pustaka Setia, 2014), hlm 49

${ }^{10}$ Moh Nazir, Metode Penelitian, (Jakarta: Ghalia Indonesia, 2003), Cet Ke 5, hlm 54

${ }^{11}$ Sudarwan Danim, Menjadi Peneliti Kualitatif, (CV. Pustaka Setia, 2002), hlm 5

${ }^{12}$ Dyah Ochtorina Susanti dan A'an Efendi, Penelitian Hukum (Legal researc), (Jakarta, Sinar Grafika, 2014), hlm 110
} 


\section{PEMBAHASAN}

\section{Definisi Pembiayaan}

Menurut Undang-Undang Nomor 10 Tahun 1998 tentang Perubahan Atas Undang-Undang Nomor 7 Tahun 1992 tentang Perbankan "pembiayaan adalah penyediaan uang atau tagihan yang dipersamakan dengan itu berdasarkan persetujuan atau kesepakatan antara bank dengan pihak lain yang mewajibkan pihak yang dibiayai untuk mengembalikan uang atau tagihan tabungan setelah jangka waktu tertentu dengan imbalan atau bagi hasil"13.

Selain itu juga istilah pembiayaan dapat dilihat dalam Undang-Undang Nomor 21 tahun Tahun 2008 tentang Perbankan Syariah

"Pembiayaan adalah penyediaan dana atau tagihan yang dipersamakan dengan itu berupa:

a. $\quad$ transaksi bagi hasil dalam bentuk mudharabah dan musyarakah;

b. $\quad$ transaksi sewa-menyewa dalam bentuk ijarah atau sewa beli dalam bentuk ijarah muntahiya bittamlik;

c. transaksi jual beli dalam bentuk piutang murabahah, salam, dan istishna',

d. transaksi pinjam meminjam dalam bentuk piutang qardh; dan

e. $\quad$ transaksi sewa-menyewa jasa dalam bentuk ijarah untuk transaksi multijasa

berdasarkan persetujuan atau kesepakatan antara Bank Syariah dan/atau UUS dan pihak lain yang mewajibkan pihak yang dibiayai dan/atau diberi fasilitas dana untuk mengembalikan dana tersebut setelah jangka waktu tertentu dengan imbalan ujrah, tanpa imbalan, atau bagi hasil. ${ }^{14}$

\footnotetext{
${ }^{13}$ Lihat Pasal 1 angka 12 Undang-Undang Nomor 10 Tahun 1998

${ }^{14}$ Lihat Pasal 1 angka 25 UU Nomor 21 Tahun 2008
}

Pembiayaan yang disalurkan oleh bank syariah kepada pihak yang membutuhkan haruslah sesuai dengan prinsip-prinsip syariah, artinya produk tersebut harus bebas dari unsur riba(unsury), gharar (uncertainty), dan maysyir (speculative). Oleh karena itu, setiap investasi atau pembiayaan yang dilakukan oleh bank syariah harus sesuai dengan prinsip-prinsip atau norma-norma Islam. Ada lima segi regiulitas yang harus diterapkan dalam pembiayaan perbankan syariah. Lima segi tersebut adalah: ${ }^{15}$

a. tidak ada transaksi keuangan berbasis bunga (riba).

b. Pengenalan pajak religius atau pemberian sedekah

dan zakat.

c. Pelarangan produk produksi barang dan jasa yang bertentangan dengan sistem nilai Islam (haram).

d. Penghindaran aktivitas ekonomi yang melibatkan maysyir (judi), dan gharar (ketidak pastian).

e. Penyediaan takaful (asuransi Islam).

Pembiayaan dalam perbankan syariah menurut Al-Harran dapat dibagi tiga: ${ }^{16}$ Pertama, Return bearing financing, yaitu bentuk pembiayaan yang secara komersial menguntungkan, ketika pemilik modal mau menanggung risiko kerugian dan nasabah juga memberikan keuntungan. Kedua, Return fee finanncing, yaitu bentuk pembiayaan yang tidak untuk mencari keuntungan yang lebih ditujukan kepada orang yang membutuhkan (poor), sehingga tidak ada keuntungan yang dapat diberikan. Ketiga, Charity financing, yaitu bentuk pembiayaan yang memang diberikan kepada orang miskin dan membutuhkan, sehingga tidak klaim terhadap pokok dan keuntungan.

\section{Pengertian, Rukun, dan Syarat Akad}

${ }^{15}$ Khotibul Umam, Perbankan Syariah Dasar-dasar dan Dinamika Perkembanganya di Indonesia, (Jakarta, RajaGrafindo Persada, 2016), 102

${ }^{16}$ Ascarya, Akad dan Produk Bank Syariah, (Jakarta, RajaGrafindo Persada, 2015), 122 
Lafal akad dari lafal arab al-akad yang berarti perikatan, perjanjian dan pemufakatan al-ittifaq. Secara terminolgi fiqih, akad didefinisikan dengan:

ارتبايجاب يقبول علي وجه مشروع يثبت اثره فى محله

pertalian ijab (pernyataan melakukan ikatan) dan qabul (pernyataan menerima ikatan) seseuai kehendak syariat yang berpengaruh pada obyek perikatan. ${ }^{17}$

Menurut pengertian umum, akad adalah segala sesuatu yang dilaksanakan dengan perikatan antara dua pihak atau lebih melalui proses ijab dan kabul yang didasarkan pada ketentuan hukum Islam dan memiliki akibat hukum kepada para pihak dan objek yang diperjanjikan. ${ }^{18}$

Sedangkang menurut Kompilasi Hukum Ekonomi Syariah, akad adalah kesepakatan dalam suatu perjanjian antara dua pihak atau lebih untuk melakukan atau tidak melakukan perbuatan hukum tertentu. ${ }^{19}$

Selain itu, pengertian terkait dengan akad dapat dilihat di dalam Undang- Undang Nomor 21 Tahun 2008 tentang Perbankan Syariah, Akad adalah kesepakatan tertulis antara Bank Syariah atau UUS dan pihak lain yang memuat adanya hak dan kewajiban bagi masing-masing pihak sesuai dengan Prinsip Syariah. ${ }^{20}$

Akad merupakan salah satu elemen yang sangat penting yang harus ada dalam transaksi syariah (muamalah), karena halal haramnya harta yang didapat salah satunya ditentukan oleh aka itu sendiri. Oleh karena itu, akad haruslah dilaksanakan sebagaimana disebutkan dalam firman Allah S.W.T QS. Al-Maidah ayat 1:

17 Abd. Hadi, Memahami Akad-akad dalam Perbankan Syariah dan Dasar-dasar Hukumnya, (Surabaya, Sinar Terang, 2015), 79

${ }^{18}$ Wawan Muhwan Hariri, Hukum Perikatan Dilengkapi Hukum Perikatan Islam, (Bandung, Pustaka Setia, 2011), 243

${ }^{19}$ Lihat Pasal 20 ayat (1) Kompilasi Hukum Ekonomi Syariah

${ }^{20}$ Lihat Pasal 1 Angka 13 UU Nomor 21 Tahun 2008

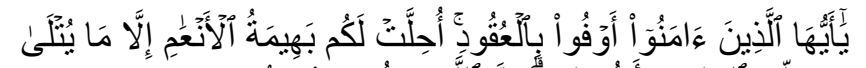

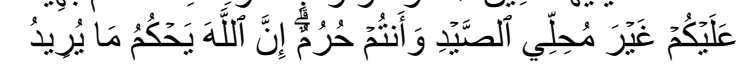

"Hai orang-orang yang beriman, penuhilah aqad-aqad itu. Dihalalkan bagimu binatang ternak, kecuali yang akan dibacakan kepadamu. (Yang demikian itu) dengan tidak menghalalkan berburu ketika kamu sedang mengerjakan haji. Sesungguhnya Allah menetapkan hukum-hukum menurut yang dikehendaki-Nya"

Rukun dalam akad menurut Kompilasi Hukum Ekonomi Syariah ada empat, yaitu: ${ }^{21}$
1) Pihak-pihak akad,
2) Obyek akad,
3) Tujuan pokok akad, dan
4) Kesepakatan

Syarat dalam akad ada empat, yaitu ${ }^{22}$

1) Syarat berlakunya akad (In'iqod). Syarat ini ada yang umum dan khusus. Syarat umum harus selalu ada pada setiap aka, seperti syarat yang harus ada pada setiap pelaku akad, objek akad dan shighah akad, akad bukan pada sesuatu yang diharamkan, dan akad pada sesuatu yang bermanfaat. Sementara itu, syarat khusus merupakan sesuatu yang harus ada pada akad-akad tertentu, seperti misalnya dua orang saksi pada akad nikah.

2) Syarat sahnya akad (Shihah), yaitu syarat yang diperlukan secara syariah agar akad berpengaruh, seperti dalam akad perdagangan harus bersih dari cacat.

Syarat sahnya akad harus terhindar dari 6 (enam) hal, yaitu: ${ }^{23}$

\footnotetext{
${ }^{21}$ Lihat Pasal 22 Kompilasi Hukum Ekonomi Syariah

22 Ascarya, Akad dan Produk Bank Syariah, (Jakarta, RajaGrafindo Persada,

2015), 35

${ }^{23}$ Mardani, Hukum Perikatan Syariah di Indonesi, (Jakarta, Sinar Grafika, 2013),
} 53 
a) Al-Jahalah (Ketidak jelasan tentang harga, jenis dan spesifikasinya, waktu pembayaran, atau lamanya opsi, dan penanggung atau penanggung jawab);

b) Al-Ikrah (Keterpaksaan);

c) Attauqit (pembatasan waktu);

d) Al-Gharar (Ada unsur kemudharatan); dan

e) Al-Syarthu al-fasid (Syarat-syaratnya rusak, seperti pemberian syarat pada pembeli untuk menjual kembali barangnya yang dibelinya kepada penjual dengan harga yang lebih murah.

3) Syarat terealisasikannya akad (Nafadz), syarat berlakunya akad yaitu pertama, adanya kepemilikan terhadap barang atau adanya otoritas (al-wilayah) untuk mengadakan akad, baik secara langsung atau perwakilan. Kedua, pada barang jasa tersebut tidak terdapat hak orang lain.

4) Syarat lazim, yaitu bahwa akad harus dilaksanakan apabila tidak ada cacat.

\section{Pengertian Pembiayaan Mudharabah}

Secara bahasa mudaharabah diambil dari kata al-dharbfi alArdh, yang berarti perjalanan untuk berniaga. ${ }^{24}$ Allah SWT. berfirman dalam surat Al-Muzammil:

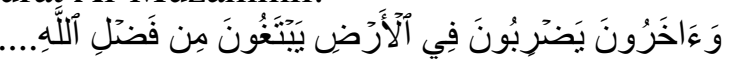

“...dan yang lainnya berjalan dimuka mencari sebagian karunia Allah",25

Makna secara bahasa yang berbeda yang ditawarkan oleh Atang Abd. Hakim, yaitu Al-Mudharabah berasal dari kata "al-

${ }^{24}$ Yadi Janwari, Lembaga Keuangan Syariah, (Bandung, Remaja Rosdakarya, 2015), 58

${ }^{25}$ Al-quran, 73:20 dharb" yang berarti al-safar (perjalanan), al-mist (seimbang), ${ }^{26}$ dan al-shinf (bagian). ${ }^{27}$

Pengertian al-mudaharabat secara terminologi dikemukakan oleh para ulama fiqih dengan redaksi yang berbeda-beda meskipun substansinya sama. Ulama Hanafiah menjelaskan, mudharabah termasuk perkongsian dalam keuntungan (شركة في الربح), dan dengan demikian, ia adalah akad perkongsian keuntungan atas harta yang diberikan oleh pemilik moda kepada pelaku usaha (بقد الثركة في الربح (بمال من احد الجنين و عمل من الاخر

Pengertian dari mudharabah atau qirad adalah penanaman dana dari pemilik dana (shahibul maal) kepada pengelola dana (mudharib) untuk melakukan kegiatan usaha tertentu, dengan pembagian menggunakan metode bagi untung dan rugi (proffit and loss sharing) atau metode bagi pendapatan (revenue sharing) antara kedua belah pihak berdasarkan nisbah yang telah disepakati sebelumnya. Kentungan yang ada dibagi sesuai dengan syarat-syarat yang telah disepakati, sedangkan jika terjadi kerugian, maka dibebankan kepada pemilik harta saja. Sementara orang yang mengusahakan menanggung kerugian dalam usahanya, sehingga tidak perlu diberi beban kerugian yang lain. ${ }^{28}$

Muhammad Syafii Antonio mendefinisikan mudharabah adalah akad kerja sama usaha antara dua pihak dimana pihak pertama (shahibul maal) menyediakan seluruh (100\%) modal, sedangkan pihak lainnya menjadi pengelola. Keuntungan usaha dibagi menurut kesepakatan yang dituangkan dalam kontrak, sedangkan apabila ruggi ditanggung oleh pemilik modal selama kerugian itu bukan akibat kelalaian si pengelola. Seandainya

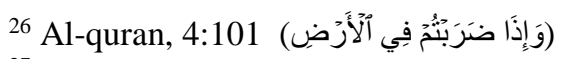

${ }^{27}$ Atang Abd. Hakim, Fiqih Perbankan Syariah Transformasi Fiqih Muamalah ke dalam Peraturan Perundang-undangan, (Bandung, Refika Aditama, 2011), 213

${ }^{28}$ Khotibul Umam, Perbankan Syariah Dasar-dasar dan Dinamika

Perkembanganya di Indonesia, (Jakarta, RajaGrafindo Persada, 2016), 131 
kerugian itu kerana kecurangan atau kelalaian si pengelola, maka si pengelola harus bertanggung jawab atas kerugian tersebut. ${ }^{29}$

Pembiayaan mudharabah dalam praktik di perbankan syariah Indonesia juga tidak sama persis dengan konsep klasik mudharabah. Perbedaan krakteristik pokok pembiayaan mudharabah dalam literatur kalasik dan praktik Indonesia dapat dilihat pada Tabel 2.1

Tabel 2.1 Perbandingan Krakteristik Pokok Pembiayaan Mudharabah dalam Literatur Klasik dan Praktik di Indonesia

\begin{tabular}{|c|c|c|}
\hline $\begin{array}{l}\text { Krakteristik } \\
\text { Pokok }\end{array}$ & $\begin{array}{l}\text { Prakti } \\
\text { k Klasik }\end{array}$ & $\begin{array}{l}\text { Praktik } \\
\text { Indonesia }\end{array}$ \\
\hline Tujuan transaksi & $\begin{array}{l}\text { Invest } \\
\text { asi dengan } \\
\text { pihak lain } \\
\text { (mudharib) }\end{array}$ & $\begin{array}{l}\text { Pembiayaan/pen } \\
\text { yediaan fasilitas }\end{array}$ \\
\hline Pengelola usaha & $\begin{array}{ll} & \text { Mudh } \\
\text { arib } & \end{array}$ & $\begin{array}{l}\text { Nasabah } \\
\text { (mudharib) }\end{array}$ \\
\hline Pembagian hasil & $\begin{array}{lr} & \text { Profit } \\
\text { and } & \text { loss } \\
\text { sharing } & \end{array}$ & Revenue sharing \\
\hline $\begin{array}{l}\text { Penentuan } \\
\text { nisbah bagi hasil }\end{array}$ & $\begin{array}{l}\text { Nisba } \\
\text { h bagi hasil } \\
\text { tetap selama } \\
\text { periode } \\
\text { perjanjian }\end{array}$ & 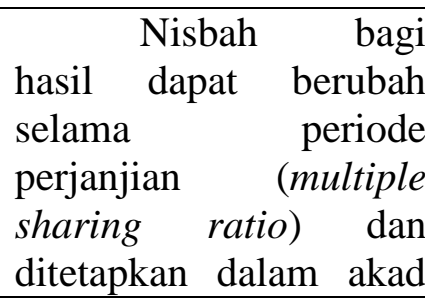 \\
\hline
\end{tabular}

${ }^{29}$ Muhammad Syafii Antonio, Bank Syariah Dari Teori Ke Praktik, (Jakarta, Gema Insani, 2017), 95

\begin{tabular}{|c|c|c|}
\hline & & di awal periode kontrak \\
\hline $\begin{array}{l}\text { Pembayaran } \\
\text { pokok }\end{array}$ & \begin{tabular}{lr} 
& Dilak \\
ukan & satu \\
kali & diakhir \\
\multicolumn{2}{l|}{ periode }
\end{tabular} & $\begin{array}{lcc} & \text { (i) } & \text { Dilakuka } \\
\mathrm{n} & \text { satu kali } & \text { diakhir } \\
\text { periode, atau } & \\
& \text { (ii) } & \text { Diangsur }\end{array}$ \\
\hline $\begin{array}{l}\text { Pembayaran } \\
\text { bagi hasil }\end{array}$ & $\begin{array}{lr} & \text { Dilak } \\
\text { ukan } & \text { satu } \\
\text { kali di } & \text { akhir } \\
\text { periode } & \end{array}$ & Diangsur \\
\hline Profit rate & $\begin{array}{l}\text { Dihit } \\
\text { ung satu kali } \\
\text { di akhir } \\
\text { periode atas } \\
\text { dasar } 100 \% \\
\text { nilai } \\
\text { penempatan } \\
\text { dana investor } \\
\text { sejak awal } \\
\text { periode } \\
\text { perjanjian }\end{array}$ & $\begin{array}{l}\text { Dihitung atas } \\
\text { dasar dana awal yang } \\
\text { masih (dan dianggap) } \\
\text { digunakan oleh nasabah }\end{array}$ \\
\hline $\begin{array}{cc}\text { Dalam } & \text { hal } \\
\text { terjadi kerugian } & \end{array}$ & & $\begin{array}{l}\text { Untuk satu kali } \\
\text { angsuran pokok: (i) bagi } \\
\text { hasil dibayar periodik } \\
\text { sesuai dengan periode } \\
\text { angsuran pokok dan } \\
\text { profit rate dihitung dari } \\
\text { jumlah nominal bagi } \\
\text { hasil perdana awal } \\
100 \% \text { atau (ii) bagi hasil }\end{array}$ \\
\hline
\end{tabular}




\begin{tabular}{|l|l|l|}
\hline & & $\begin{array}{l}\text { dibayar periodik sesuai } \\
\text { dengan periode } \\
\text { angsuran pokok dan } \\
\text { profit rate dihitung dari } \\
\text { jumlah nominal dari } \\
\text { bagi hasil yang } \\
\text { didiscount karena } \\
\text { menurunnya share dana } \\
\text { bank dalam usaha } \\
\text { nasabah (decreasing } \\
\text { participation) }\end{array}$ \\
\hline Kolateral & Tanpa \\
& jaminan & \multicolumn{2}{|c|}{ Dengan jaminan } \\
\hline
\end{tabular}

Secara umum, mudharabah terbagi menjadi dua jenis: mudharabah mutlaqah dan mudharabah muqayyadah. ${ }^{30}$

\section{a. Mudharabah Mutlaqah}

Mudharabah mutlaqahadalah bentuk kerjasama antara shahibul maal dan mudharib yang cakupannya sangat luas dan tidak dibatasi oleh spesifikasi jenis usaha, waktu dan daerah bisnis. Dalam pembahasan fiqih ulama salafus saleh seringkali dicontohkan dengan ungkapan if al ma syi'ta (lakukanlah sesukamu) dari shahibul maal ke mudharib yang memberi kekuasaan sangat besar. Dalam istilah bahasa Inggrisnya dikenal dengan istilah unrestricted investment (URIA) Mudharabah mutlaqah. Namun demikian, apabila dipandang perlu, shahibul maal boleh menetapkan batasanbatasan atau syarat-syarat tertentu guna menyelamatkan modalnya dari risiko kerugian.

\footnotetext{
${ }^{30}$ Muhammad Syafii Antonio, Bank Syariah Dari Teori Ke Praktik, (Depok, Gema Insani, 2017), 97
}

\section{b. Mudharabah Muqayyadah}

Mudharabah Muqayyadah atau disebut juga dengan istilah retricted mudharabah/specifed mudharabah atau dalam istilah Inggrisnya disebut retricted invesment account (RIA)adalah kebalikan dari mudharabah mutlaqahsi mudharib dibatasi oleh spesifikasi jenis usaha, waktu atau tempat usaha. Adanya pembatasan ini seringkali mencerminkan kecendrungan umum si shahibul maal dalam memasuki jenis dunia usaha.

\section{Strategi Perbankan dalam Menghadapi Pembiayan \\ Mudaharabah yang Bermaslah}

Penyebab terjadinya pembiayaan bermasalah adalah kesulitan-kesulitan keuangan yang dihadapi nasabah. Penyebab kesulitan keuangan tersebut dapat dibagi kedalam dua faktor, yakni faktor internal dan faktor eksternal.

BRI Syariah pamekasan dalam menghadapi pembiayaan dengan akad mudharabah yang bermasalah, mengunakan dua metode pendekatan, yakni pendekatan pra menjadi calon nasabah/mudharib dan pendekatan pasca menjadi nasabah/mudharib. Hal itu dilakukan agar semua yang telah direncakan oleh pihak bank terkait dengan penyaluran pembiayaan denga akad mudharabah berjalan sesuai dengan yang diinginkan oleh pihak atau setidaknya meminimalisir terjadinya pembiyaan yang bermasalah.

Pertama, pendekatan pra menjadi nasabah . Analisis yang dilkukan oleh pihak bank terhadap calon nasabah dengan permohonan pembiayaan mudharabah adalah sebagai berikut:

1. Analisa terhadap kriteria $5 \mathrm{C}$ (chracter, capital, capacity, condition of economic, dan collateral).

2. Bank hanya akan membiayai terhadap usaha-usaha yang produktif. Hal ini sesuai dengan Fatwa DSN Nomor 07/DSNMUI/IV/2000 tentang Pembiayaan Mudharabah (Qiradh) poin pertama angka satu yang menyatakan "Pembiayaan Mudharabah 
adalah pembiayaan yang disalurkan oleh LKS kepada pihak lain untuk suatu usaha yang produktif".

3. Bank tidak akan memberikan pembiayaan terhadap calon debitur yang terkena BI Checking.

4. Bank tidak diperkenankan memberikan pembiayaan kepada usaha-usaha yang sudah dari awal pemeriksaan oleh bank ternyata usaha yang dijalankan tidak sehat.

5. Bank tidak memberikan pembiayaan melebihi batas maksimum pembiayaan. melalui:

Kedua, Pendekatan pasca menjadi nasabah. antara lain

1) Penjawalan kembali (rescheduling), yaitu penjadwalan pembayaran kewajiban nasabah atau jangka waktunya.

Hal ini dilakukan dengan cara, pihak BRI Syariah Pamekasan akan melakukan penjadwalan ulang dari jadwal yang sudah ditetapkan sebelunya, misalnya dengan cara memberikan waktu yang lebih lama yang biasanya angsurannya pengembalian modalnya adalah satu bulan diubah menjadi dua bulan sekali. Atau bisa saja pihak BRI Syariah Pamekasan akan memperpanjang jangka waktu pelunasannya.

2) Persyaratan kembali (reconditioning), yaitu perubhan sebagian atau seluruh persyaratan pembiayaan tanpa menambah sisa pokok kewajiban nasabah yang harus dibayarkan kepada bank. Misalnya dengan cara perubahan nisbah dalam pembiayaan mudharabah atau perubahan proyeksi bagi hasil dan pemberian potongan. ${ }^{31}$

3) Penataan kembali (restructuring), yaitu peubahan persyaratan pembiayaan misalnya penambahan dana fasilitas pembiayaan bank, hal ini bertujuan agar kegiatan usaha nasabah dapa kembali berjalan dengan baik.
Dalam Surat Edaran Bank Indonesia No. 10/34/DPbS, 22 Oktober 2008 Perihal: Restrukturisasi Pembiayaan bagi Bank Umum Syariah dan Unit Usaha Syariah diatur secara lebih teknis, yakni bahwa:

1. Pembiayaan yang akan direstrukturisasi dianalis berdasarkan:

a. Prospek usaha nasabah dan/atau kemampuan membayar sesuai proyeksi arus kas untuk nasabah pembiayaan produktif; atau

b. Kemampuan membayar sesuai proyeksi arus kasuntuk nasabah pembiayaan non produktif.

2. Pembiyaan kepada pihak terkait yang akan direstrukturisasi dianalis oleh konsultan keuangan independen yang memiliki izin usaha dan reputasi yang baik.

3. Analisi yang dilakukan BUS atau UUS dan konsultan keuangan independen terhadap pembiayaan yang direstrukturisasi pembiayaan didokumentasikan secara lengkap dan jelas.

4. Restrukturisasi pembiayaan dituangkan dalam addendum akad pembiayaan dan/atau melakukan akad pembiayaan yang baru mengikuti krakteristrik masing-masing bentuk pembiayaan.

\section{5.}

\section{KESIMPULAN}

Berdasarkan dari hasil penelitian yang telah dilakukan oleh penulis, maka dapat ditarik kesimpulan sebagai berikut.

1. Penerapan pembiayaan dengan akad Mudharabah yang di laksanakan di BRI Syariah Pamekasan apabila di tinjau dari segi hukum Islam sudah sah karena sudah memenuhi syarat-syarat sahnya akad, serta sudah sesuia dengan peraturan yang berlaku di Indonesia yakni Undang-Undang Nomor 21 Tahun 2008 tentang Perbankan Syariah serta sudah sesuai dengan Fatwa Dewan syariah Nasional-Majelis Ulama Indonesia No : 7/DSNMUI/IV/2000 
tentang Pembiayaan Mudharabah, di sana telah di terangkan dasar hukumnya, dan apabila relisasinya tidak sesuai dengan fatwa, maka dewan pengawas syariah sebagai kepanjangan Dewan Syariah nasinal akan menegurnya.

2. Strategi Perbankan Syariah dalam menghadapi pembiayaan yang bermasalah baik itu dari faktor internal dan faktor eksternal, dilakukan dengan menggunakan dua metode analisa. Analisa yang pertamai, adalah analisa yang dilakukan pra menjadi nasabah, baik itu berupa kepada diri calon nasabah dan/atau kepada usaha yang akan diberikan pembiayaan oleh pihak. Kedua, adalah analisa pasca menjadi nasabah. Analisa ini dilakukan ketika seseorang telah menjadi nasabah dan mengalami pembiayaan yang bermasalah, ini dilakukan dengan cara restrukturisasi pembiayaan bagi nasabah yang dinyatakan bermasalah.

\section{SARAN}

1. Bagi pihak bank agar lebih meningkatkat inovasi pembiayaan mudharabah, sehingga pembiayaan mudharabah menjadi salah satu pilihan bagi masyarakat dalam membangun perekonomian. Selain itu juga bank lebih banyak mensosialisasikan produk pembiayaan perbankan syariah kepada masyarakat umum khususnya masyarakat muslim .

2. Bank harus lebih hati-hati dalam penyaluran pembiayaan bermasalah, artinya bank tidak hanya mementingkan target penyaluran oleh perusahan, tetapi juga harus memikir resiko yang akan dihadapi jika nanti pembiayaan yang diberikan kepada nasabah menjadi pembiayaan yang bermasalah (non performing financing).

\section{DAFTAR PUSTAKA}

A. Karim , Adiwarman. Bank Islam Analisis Fiqih dan Keuangan. Cetakan ke-12. Depok: RajaGrafindo Persada, 2017.

Abdullah, Boedi . Beni Ahmad Saebani. Metode Penelitian Ekonomi Islam Muamalah. Bandung: CV. Pustaka Setia, 2014.

Ali, Zainuddin. MetodePenelitianHukum. Jakarta: Sinar Grafika, 2009.

Antonio, Muhammad, Syafii. Bank Syariah Dari Teori Ke Praktik. Cetakan Keduapuluh Tujuh, Jakarta: Gema Insani, 2017.

Ascarya. Akad dan Produk Bank Syariah. Jakarta: RajaGrafindo Persada, 2015.

Danim, Sudarwan. Menjadi Peneliti Kualitatif, Bandung: Pustaka Setia, 2002.

Hadi, Abd. Memahami Akad-akad dalam Perbankan Syariah dan Dasar-dasar Hukumnya. Surabaya: Sinar Terang, 2015.

Hakim, Atang, Abd Fiqih. Perbankan Syariah Transformasi Fiqih Muamalah ke dalam Peraturan Perundang-undangan. Bandung: Refika Aditama, 2011.

Hasan, M. Iqbal. Metodologi Penelitian dan Aplikasinya. Bogor: Ghalia Indonesia, 2002.

Hariri, Wawan, Muhwan. Hukum Perikatan Dilengkapi Hukum Perikatan Islam. Bandung: Pustaka Setia, 2011.

Ismail, Perbankan Syariah. Cetakan ke-3. Jakarta: Kencana, 2014.

Janwari, Yadi. Lembaga Keuangan Syariah. Bandung: Remaja Rosdakarya, 2015.

Lusiana Elizabeth, Manajemen Resiko dalam Transaksi Pembiayaan Mudaharabah. Tesis S2 Program Sarjana PSTT UI Jakarta, 2009.

Mardani, Hukum Perikatan Syariah di Indonesia. Jakarta: Sinar Grafika, 2013. 
Muhammad, Sistem \& Prosedur Operasional Bank Syariah. Yogyakarta, UII Press ,2000.

Nazir, Moh. Metode Penelitian. Jakarta: Ghalia Indonesia, 2003.

Ning Karnawijaya. Kegiatan Bank Syariah Mandiri (BSM) dalam Pemberian Kredit Mudharabah Tinjauan Aspek Yuridis. Tesis, Program Magister Pasca Sarjana Universitas Islam Negeri Kalijaga Yogyakarta, 2009.

Sugiyono, Metodologi Penelitian Kualitati Kuantitatif dan $R \& D$. Bandung: Alfa Beta, 2008.

Susanti, Dyah, Ochtorina dan A'an Efendi, Penelitian Hukum (Legal researc). Jakarta: Sinar Grafika, 2014.

Umam, Khotibul. Perbankan Syariah Dasar-dasar dan Dinamika Perkembanganya di Indonesia. Jakarta: RajaGrafindo Persada, 2016.

Usanti, Trisadini. Abd. Somad, Transaksi Bank Syariah. Jakarta: Bumi Angkasa, 2015.

http://www.republika.co.id/berita/dunia-islam/islamnusantara/15/05/27/noywh5-inilah-10-negara-denganpopulasi-muslim-terbesar-di-dunia diakses tanggal 15 Februari 2018.

BRI Syariah, "Sejarah Bank BRI Syariah", dalam http://www.bri syariah.co.id/?q=sejarah, diakses pada 27 Januari 2018. 